\title{
Collective Portrait of Iowa Civil War Generals
}

\author{
By Richard Hellie
}

Of the 75,000 Iowa men who fought during the tragic years of the Civil War, 66 were to become generals. The intent of this article is to present a collective portait of these 66 men, their backgrounds and training previous to the war, and the effect of the war on their postwar lives.

The median age of these 66 Iowa men in the year 1861 was 33, which by today's standards is quite low. Curtis, at the age of 56, was the oldest of the group. This is surprisingly young, considering the fact that there was available at the time a large reserve of veterans who had served during the Mexican War. The youngest general was Stibbs who was later to sit on the panel which tried Wirz, the Confederate commander of the Andersonville prison. Age, however, seems to have made little difference in attainment of rank so far as the whole pool of generals is concerned. The average age of the generals was probably higher than that of the enlisted men, but age itself was not decisive when the most successful and courageous generals were sorted out. The average age of major generals was 37 , brevet major generals 30 , brigadier generals 39 , and brevet brigadier generals 34 .

None of the generals who commanded Iowa regiments was born in Iowa. Many came from larger states-New York and Pennsylvania-while most of the others came from nearby Illinois, Indiana, Kentucky and Ohio. Only a few came from the New England and border states and none from the deep South. The length of time that these men lived in Iowa before the war was about 10 years. With few exceptions, all of the group had been in Iowa at least three years before the war. This was essential, for most of them were elected officers by their fellow citizens, and for this to occur, they had to be known and respected in their communities.

Education was an important factor in the army, even a century ago. Although the relatively uneducated were able to 
be elected by their fellow men as officers, very few of them attained the higher general rankings. About three-fourths of the group had formal training of some sort beyond common school. Among the best educated were Belknap who graduated from Princeton, and Noble who graduated from Yale. Almost half of the men had studied law and one-sixth had attended West Point. A significant number had gone into merchandising, banking, education, engineering and journalism, and many had been active in politics. This is in marked contrast to the average soldier who fought in the war, for the census records from Iowa before 1861 list mostly men of occupations such as farmer, laborer, miner, cooper, and blacksmith. Very few of the generals had engaged in these professions, and as a group, those who had did not attain as high a rank as did those engaged in banking, engineering, military, and railroading.

Politicians did well as shown by the fact that one of the four major generals was in political life before the war, seven of the 15 brevet major generals, two of the nine brigadier generals, and eight of the 38 brevet brigadier generals. From this it might be inferred that the men who became generals of Iowa regiments were relatively prominent men on the way up in society before the war.

When the war broke out, many of the generals-to-be rushed to form companies, and after so doing, were usually elected as officers by the recruits. Of the men who had engaged in politics there seems to be a correspondingly higher entry ranking than the non-political. This could be expected, for men active in public life would likely be among the more popular leaders at the outbreak of war.

A large proportion of the group under discussion distinguished themselves by their bravery in the notable battles of Wilson's Creek, Pea Ridge, Shiloh, Corinth, and Vicksburg. They were considered heroes by their fellow men, and this was a frequent reason for the awarding of their rank. Three of the four major generals were awarded their ranks after battles: Curtis after Pea Ridge, Dodge after the March to the Sea, and Herron after Prairie Grove.

There was a definite relationship between rank upon entry into the army and the highest rank attained. As a rule, those 
that entered at a higher rank left with a higher rank. Most of the men under discussion who entered the army in the lower ranks became the brevet brigadier generals. Promotion was usually right up the line with no big jumps in rank.

The problem now to be examined is the effect that service in the Civil War had on the postwar pursuits of the generals. The war took the lives of four Iowa generals-Crocker, Hill, Lauman, and Samuel Rice; consequently, they will not be included in the following discussion. There was a considerable career change by the generals after the war from their prewar occupations, and in addition, a distinct correspondence between the rank of the generals and their achievemeints in the army and later civilian success. The greatest changes wəre from education, journalism and merchandising to governmeit. Whereas fewer than ten per cent had held government positions prior to the war and less than 25 per cent immediately after the war, almost half were in govermment service prior to their deaths. Furthermore, the quality of the positions improved along with the quantity.

Aside from the carpetbaggers, a very few, if any, of the generals who had not been in prewar politics achieved any political gains from the Civil War. The carpetbaggers, of course, had their positions as a consequence of the victory of the North. Among them were over ten per cent of the generals who had commanded Iowa regiments. Most of the group, however, preferred the more secure positions in government or the more lucrative positions in private enterprise, showing that the men who had been generals were, as a group, more successful in business and government than they were in politics.

In the years between the immediate period after the Civil War and the deaths of the generals under discussion, many of the men achieved prominent positions in American life. Their fates were both sad and glorious. Heath died a tramp in Peru and Pomutz died a pauper in Russia. Dodge, on the other hand, died after a glorious career in railroading with the Union Pacific, Denver \& Gulf, Trans-Siberian Rail Road, and more than a dozen others. Weaver passed on after a notable effort on the political scene as Republican candidate for governor, representative in Congress, a Greenbacker and later Peoples 
party presidential candidate. These were the extremes. Most of the others who survived the war were successful in civilian life. Several of the men made inventions, wrote books, and were active in education. Railroading was one of the major passions of the age and many of the generals engaged in it at one time or another. Some of the considerable concentration of the generals in railroading may have resulted from their war careers, but it is also a fact that the most successful men were already associated with that business before 1861 .

Prior to the war, almost as many of the generals were Republicans as were Democrats. After the war, however, an overwhelming majority of them were Republicans. The generals probably felt more than any other group that the Democrats, who before the war had made alliance with the South, were the cause of the war and were a treasonous group to be avoided.

The men who became generals from Iowa often contributed significantly to the state prior to the war, but their distinguished, impressive careers made little or no impression on the state after the war. This was because many of the generals spent their most fruitful years outside of Iowa. Such mobility was not surprising for the 19th Century, but it was probably greater for the generals than for a similar group of men of less education, ability, and distinction.

The well-educated, up-and-coming, ambitious men who raised companies to fight in the Civil War and subsequently became generals were high caliber men who consciously or unconsciously wanted to make a mark in life. Before the war, Iowa was on the frontier where everything was fresh, relatively booming, and exciting. The war shook them up and moved them around and out of Iowa where they conceivably might otherwise have stayed. After the war they kept on moving, either to new frontiers or to new excitement, this time in big league business, government or politics. Because Iowa was no longer an exciting frontier nor in the big leagues as far as business or politics was concerned, the best educated and most ambitious men with the most to offer and the prospects of the brightest futures, forsook the state and achieved success elsewhere.

Although the construction of a valid stereotype of the Civil 
War Union general of Iowa is impossible, a definite impression does emerge from the discussion of the 66 men. The general was born outside of Iowa, well-educated by the standards of the age, was a leader in the Iowa community in which he had lived for about ten years pricr to 1861, and was about 33 when the war broke out. The general's previous experience, except for political, did not have much effect on the officer rank he received after he raised a company. After four years of war, however, the better educated, more ambitious man who had managed to enter at the higher rank became the higher ranking general. After the war, the qualified man who was forging ahead before the war, continued his climb upward; the only dramatic leap was made by the man who entered government. Because neither frontier excitement nor big league business, government, and politics were to be found in Iowa, the forceful, ambitious and adventurous man did not return to Iowa after the war, but sought his good fortune elsewhere. The general's public influence lasted about 30 years after the war, and when he died, he was, in most cases, a good Republican. Finally, the writer might add that the general epitomized the mobility and success of the 19th Century American.

* Mr. Hellie is a doctoral candidate at the University of Chicago (Department of History) and is currently working at the Harvard Russian Research Center on his dissertation.

\section{The Picture on the Cover . . .}

The sketch on the cover is of a sleigh which was used in Des Moines from 1885 to 1900 by F. M. Hubbell. Hubbell used it during the winter months to travel from his home, Terrace Hill, at 2900 Grand, to his office at 5th and Mulberry. It is likely that this particular sleigh was made to order since it has a second seat which is built up for a driver.

It was donated to the State Department of History and Archives in 1933 by F. C. Hubbell and is currently on display in the museum. 
Copyright of Annals of Iowa is the property of State of Iowa, by \& through the State Historical Society of Iowa and its content may not be copied or emailed to multiple sites or posted to a listserv without the copyright holder's express written permission. However, users may print, download, or email articles for individual use. 